\title{
Career Muslim Women and Religiosity in Indonesia's Digital Era: A Perspective of Islamic Education
}

\author{
L Muhtifah $^{1}$, Z H Prasojo ${ }^{2}$ \\ Institut Agama Islam Negeri Pontianak, Kalimantan Barat, Indonesia ${ }^{1,2}$ \\ $\left\{\underline{\text { laily_azhar@yahoo.co.id }}{ }^{1}\right.$, zaestain@yahoo.com $\left.{ }^{2}\right\}$
}

\begin{abstract}
Religiosity is spiritual expressions related to the system of beliefs, values, and laws. A Muslim woman who is religious in her daily activities has a religious attitude. Her position in the perspective of Islamic education faces a challenge, especially in the current digital era. This paper is an attempt to answer the questions of religious characteristics, religious behaviors, and dimensions among the Indonesian Muslim woman. The data was obtained from the results of in-depth interviews from the key informants from five zones of the archipelago in Indonesia and was compared to document studies. The results showed that first, the religious characteristics of Indonesian Muslim women having a career in the digital era are rich in faith, diligent worship, and noble characters. Second, their behaviors and religious dimensions are related to the aspects of beliefs, worships or practice, consequences, and religious knowledge. This study concluded that religiosity is an implication of the depth and maturity of Muslim women. Muslim women might become religious in their manifested career life formed through a unified and integrated dimension. The digital age is a tool to facilitate belief as a guideline in a career.
\end{abstract}

Keywords: Religiosity, Muslim Women, Career, Islamic Education

\section{Introduction}

Feminism movements, as the implication of the development of the digital era in Islamic education, has made equality, justice, and emancipation among Muslim women develop rapidly in society. Muslim and female participation rates in education and employment have increased over time, coupled with many government programs that support the achievement of gender equality. Almost all administrative and legal arrangements give a percentage of women's participation and even priorities in the administration of the state.

The breakthrough of the digital world, with the continuation of modernization, has led to the deterioration of Muslim women characters. Women who were initially reluctant to hold a strategic role, they now can surpass men. The equal rights and obligations between men and women are now out of question. It seemed that a gray area that causes disputes on the true nature of women in the phase of their reproductive cycle has been now abandoned because 
they pursue the goals of worldly success. This phenomenon has happened in Indonesia, although it has not been evenly distributed. The impact of this case was also quite significant.

For this reason, Islam put ranks the women of faith and knowledge in a high place. Islam, through comprehensive education, teaches the concept of Mukmin Ulul Albab [1]. It is proper that Muslim women have the value of the characteristics of excellence. The superiority in this discussion focuses on the concept of taqwa or awareness of the existence of God. This concept is called an Islamic religiosity model, which is interpreted as a multidimensional variation in religiosity in aspects of knowledge, beliefs, practices, consequences, and the realization of excellence [2]. It is believed that this model is reflected in the dominant aspects of Muslim women's behaviors in a career. Magill and Rodriquez [3] said that religious behavior is the wholeness of one's attitude towards his or her beliefs both in general and in particular, measured in intensity and to what extent he or she lives according to religious beliefs.

The enormity of the sophisticated digital age has opened various information and implications for the careers of Indonesian Muslim women. Islamic religiosity behaviors need to be possessed by Indonesian Muslim women in order to balance the successes of the world and the hereafter. For this reason, it is interesting to conduct a systematic study of how successful Muslim women are at work.

Before going into further the result and discussion, it is quite important to shed light on some concepts used in this research.

Islamic religiosity has varying perceptions. Religiosity is not only multidimensional but also multifaceted [4]. For Al-Goaib [5], Islamic religiosity is a commitment to the fundamentals of Islam through the fulfillment of the rights of God, protection of others' rights, observance to God's commands, avoidance of evil deeds, and worships. Individuals who are characterized as religious are those who do not only hold certain religious beliefs but also practice them in everyday life [6].

Shamsuddin [2] proposed a model of Islamic religiosity represented by the concept of taqwa (God-consciousness), the variables of which include knowledge (' $\mathrm{llm} / \mathrm{ma}$ ' $\mathrm{rifah}$ ), beliefs (faith), practice (charity), consequences and realization of excellence (Ihsan). Mohsen [7] gave the same opinion (2007) in which he said that Islamic religiosity is a concept that is embedded in taqwa. Religious personality includes a variety of routines and habits of behaviors that are not only directly related to God but also the interaction of human beings (muamalat), for example, family relationship, fellow humans and other creations (animals, natural environment creatures, etc.,) as known as public worship.

The concept of religiosity in Islam based on experts has a different point of view. Religiosity in the Muslim personality index conceptualizes religiosity as representative of the principle of monotheism or divine unity [8]. The construct of religiosity is developed based on the background of the definition of the religion of Islam and its extensions, and the perspective framework of the religion of Islam is Islam, one's faith and one's faith. Thus, the construct of religiosity emphasizes bodily actions or human activities (Islam), thoughts or understanding of God (faith), and the spirit or actualization of virtue and goodness or Ihsan [9].

Islamic religiosity consists of two: the first is the Islamic worldview about the monotheism paradigm, which is rooted in basic knowledge, beliefs, and understanding and six pillars of faith; and the second is religious personality related to public worship and exclusive worship. General worship, namely the six pillars of Islam and behavior related to a direct relationship with God and specific worship related to muamalat. Muamalat relates to human relations and human relations with other creatures [8].

Studies on women in Muslim countries have confirmed variations in how Muslim women live and think. Clarifying some general and specific ideas about career Muslim women 
in Indonesia is very important at work and career advancement from an Islamic perspective. This explanation has a relationship with the characteristics of their religiosity. It is also linked their religious behavior and the dominant characteristics in a career.

Gender equality between males and women is not an obstacle for women in pursuing a career. Azmi et al [10] stated that the obstacles in the brilliance of women's careers were more about their abilities and character. Mahudin et al. [9] stated that the Islamic religiosity of a worker shows a positive correlation with job satisfaction, positive work behavior, workplace integrity, and organizational commitment. There is an indication that will lead to professional abilities and characters of the worker, whether female or male.

The career field of Muslim women in the digital age is overgrowing and diverse throughout the world and Muslim societies. Scientific literature began to see fairly the national, social, ethnic, and political diversity in reflecting the complexity of their lives. Some literature is questioning simplified assumptions about the importance of Islam in shaping the lives of Muslim women. The enormous diversity of lives denies the idea that a single factor "Islam" can be a significant determinant of the status and welfare of Muslim women [11].

Stowasser [12] asserts domesticity is defined as "the core of women's social truth, indeed an important criterion of the citizenship of true Muslim women in their faith community." In his traditional role as wife and mother, Muslim women said Stowasser said [12] that Muslim women are expected to fight for the "survival of the Islamic way of life" perhaps at the expense of their individuality. It appears that, in accepting his centrality as the preserver of Islamic values, he must allow that not only his determined role is limited to one domesticity, but the qualities that support the display of Islamic values are also the same. The primary role of Muslim women as wives and mothers focuses on it and incorporates it in the preservation of Islamic values.

The concept of education in Islam cannot be separated from human notions. Because knowledge is an effort to realize the idea of human beings that Islam seizes. The Islamic conception of human beings is that they multidimensional, and multi-potential creatures; in Islam, that should also develop multifaceted and multi-potential meanings and characteristics [13]. The objectives of Islamic education are part of the high goals of Islam about humanity, the cosmic universe, and life. The balance should exist between the spiritual, the material, the intellectual, and the social needs of people (Abdul Wahab Abdus Salam Thawilah, 2008M / $1429 \mathrm{H})$. The nature of religious concepts, including the concept of religiosity in Islam when associated with Islamic education, is relevant to the concept of fitrah.

The concept of fitrah has a relationship with religion that emphasizes the approach of faith, because, every human being born carries the potential called the possibility of believing in God or the language of religion is monotheism. The definition of fitrah in the Qur'an is a description that God created humans by being given religious instincts, namely the religion of monotheism. Therefore, humans who are not religious monotheism are deviations from their nature. The principle of monotheism is the main principle in Islamic education today. The belief that God is the only God encompasses all things, and almighty has Absolute Power.

This article limits the discussion of the concept of Islamic Education to the planning required. The essential plan contains three aspects: the sources and the basis of Islamic education, the meaning, and purpose of Islamic learning and the duties and functions of Islamic knowledge. It is necessary that planning needs to be contextualized within the religiosity of Muslim women so they will have a strong foundation in their careers. The basic plan of planning an Islamic education is flexible, depending on the depth and breadth of the discussion. 


\section{Method}

This preliminary study was carried out through literature studies and interviews. The results of the initial research are used as consideration for developing models of measurement of Muslim religiosity among Muslim women who pursue careers in the digital age according to the perspective of Islamic education. The product is an inventory of several variables and the items of female Muslim religiosity in careers that are needed in the instrument to measure the level of female Muslim career religiosity. This research is the initial stage in conducting Research and Development (R\&D). That is, conducting a study or initial research to look for research findings related to the products to be developed. In this case, a model of religiosity of a career Muslim woman was developed in the digital age in Indonesia from the perspective of Islamic Education.

The informants in this study were five career Muslim women from the teaching profession, lecturers, and business people (entrepreneurs). The five respondents were selected based on a purposive sampling technique where the main criterion was the representation of five zones of the Indonesian archipelago, namely Java, Sumatra, Kalimantan, Sulawesi, and Papua in the field of Islamic education.

\section{Result and Discussion}

This research found three answers in regard to the religiosity of Muslim women who pursue a career from the perspective of Islamic education.

Firstly, the religious characteristics of Indonesian Muslim women in career according to the perspective of Islamic education include three sub-characteristics, including faithful to religion, worship or religious practice, and noble characters found with the following description:

The detailed description of the sub-character of faith in religion is made clear that a Muslim woman has the responsibility to worship. Worship is the morality of hablumminallah (Muslim relationship with God). They believed that psychologically what they do is something beneficial for their lives, and of course, it was God's mandate. They should behave sincerely without interference from anyone. A Muslim woman is very sure of the existence of her God because she has faith that her life and death belong only to Allah, whatever she is working at home or pursuing a career outside the home. For her, all of them is a form of worshiping her God. Also, she has complete confidence in her observance and sensitivity to the social environment. She is diligent, secure, and steadfast in practicing worship.

The sub-character of worship or religious practices or observance to worship indicated that a Muslim woman has a strong observance of it. She is diligently praying five times a day, especially Dhuhr and Asr prayers, in mosques or prayer rooms at her workplace. She attempts as far as possible to be on time in carrying the prayers. She also reminded and motivated her colleagues to worship and attend religious activities.

The sub-character formulation of the noble character stated that a Muslim woman is of good character and provides a direct example of what she has done. Furthermore, the character is more towards morality to God by observing worship and praying on time. Apart from that, it includes also morals to her fellow human beings, such as greeting each other, being friendly, polite, smiling, cooperating and helping each other; being honest, humble, and always praying five times a day. She is willing to share the experiences she knows with others. 
Secondly, the religious behaviors of Indonesian Muslim women pursuing a career can be represented in three following sub-characteristics.

The sub-characteristics of faith/belief are made clear that Indonesian a Muslim woman prioritizes the values of worship over other values. She always starts by mentioning the name of God as one of the beliefs that in a career there is always a substance that monitors her identity as a Muslim woman. She is also working responsibly for the world and for the afterlife. A Muslim woman makes a balance between her work and worship. Then, she is very confident in carrying out the pillars of Islam. She always strives to be an ideal Muslim woman by consuming halal foods, trying to be professional in the work environment, getting along with non-Muslims in a valuable way, and respecting each other's beliefs.

The sub-characteristic of worship patterns or religious practices are shown the consistency of an Indonesian Muslim woman to pray, especially dhuhr, in the congregation at the office, fasting, reading the Qur'an (tadarrus), and saying greetings. She is also inviting friends to pray, guiding children to pray and reading at school or home, reading prayers and basmalah every time she starts a lesson or activity, and actively attend Islamic holidays, sunnah prayers/duha, and others.

The sub-characteristics of religious knowledge and experience are clear from the consistency of a Muslim woman for lifelong learning by diligently attending studies. Generally, she has a standard religious knowledge with the criteria of faith, Islam, Ihsan, science, and charity. She is willing to share the experiences he knows with others.

Thirdly, the dominant dimensions in the religious behaviors of Indonesian Muslim women in their careers are two sub-characteristics. The first is beliefs or worship and practice. That is, a Muslim woman who pursues a career has full faith in her religion. This aspect becomes dominant because religious behavior is based on an awareness of the existence of God. She performs prayers after teaching, invites friends to pray, guides children to pray and recites at school, recites prayers, and says Bismillah (in the name of Allah) before working. She performs a corpse prayer during ta 'ziyah, does a duha prayer, fasting, and actively involves in Ramadan activities. She has confidence, knowledge, and practice of worship. She seeks to place herself in a religious environment that is very influential in motivating her to worship. The second dominant sub-characteristic is morals and religious knowledge. A Muslim woman who has a career shows a precise and disciplined dimension of responsibility. She also has faith in Islam as well as ihsan in every aspect of her life.

We conducted a study or preliminary research to look for the development of a model for evaluating female Muslim religiosity in a career perspective of Islamic education and its products. General research on working Muslim women will not emerge from a work-family except among those who are more religious. If Muslim women academics have limited religiosity, then the work-family responsibilities will affect their well-being. It further emphasized that religion plays an essential role as a moderator for work-family in developing the welfare of Muslim women academics. The moderate influence of religion on the relationship between work-family and the well-being of Muslim women academics is statistically important.

In particular, as explained in the previous paragraph, the analysis of the religious characteristics of Indonesian Muslim women showed that they have religious personalities in their careers as well as full faith, ritual observance, noble characters, and the responsibility to worship. Worshiping is the morality of Muslim women in their relation to God (hablumminallah). This statement makes it clear that in self-development, Muslim women can place faith in a career, where they again become more obedient and loyal to Allah Swt. Islam places much emphasis on "self-development" where an individual takes the responsibility for 
understanding the purpose of human life. The Qur'an itself asserted that a person is responsible for her actions. As it is stated in the Qur'an Surah Al-An'am: 164: "Say (Muhammad). 'Am I worthy of seeking God, but Allah, even though He is the Lord of all things? Every sinner is himself responsible. Also, a person will not carry the burden of another sin. Then, you will return to your Lord, and he will tell you what you were previously at odds with."

The three main themes that shape habluminallah for Muslim women in career are faith, worship, and morals. Each theme has several sub-themes that describe practices or characteristics that establish hablumminallah. In this light, they maintain aspects of the faith by instilling it in God. True faith in God is a significant milestone in any business and work [14]. The concept of values in moral education is based on the Qur'an and Hadith and aims to develop favorable persons. Akhlaq Islamiyyah is a manifestation of the monotheistic worldview in one's daily actions, which presupposes a way of life that demands constant and sustained awareness, not in the present world (al-dunya) but also life in the hereafter.

Based on the second findings, this result proves that the dimensions of religious behavior of Muslim women in careers in the digital age were found to be closely related to the aspects of beliefs, worship or spiritual practices, and knowledge. The three aspects are balanced between work and worship, between the world and the hereafter, and between hablumminallah and hablumminannaas (relations with a social life), and between faith and science. The balance of religious behavior is based on a strong belief in Allah SWT. Thus, the behaviors and religiosity of Muslim women in their careers fall into the behavior of "believers," "Muslims," "Muhsin," and "Ulul Albab." Muniaty (2014 p. 20) outlined that religious behaviors will be seen from a person's personality if he grows up in an environment that processes, educates, and adapts Islamic teachings in their daily lives. A person's religious behavior will be shown from the level of involvement in daily life (morals or ways) related to her beliefs (faith) and rituals or worship [15].

Religious behaviors come from the side of every human life and not only occur when she performs rituals or religious activities but also when she does other activities that are driven by her religious beliefs and beliefs [3]. There are two relationships between a person's attitude and ways of being religious, namely intrinsic and extrinsic attitudes. Fundamental ways include consistency in implementing religious guidelines as the ultimate goal, and its presence in the center of one's personality so that she always takes her religious values seriously throughout her life [16]. Intrinsic individuals consider that her need is insignificant if she is not aligned with the teachings of her religion and never compromise to integrate beliefs under any circumstances. She shall internalize his life to follow the teachings of her religion, and religion adequately serves as a framework for living life [17]. A Muslim's noble behaviors will be built on the framework of his relationship as a human being with God that is related to his obligation to implement Allah's commands, and of her relationship between humans, that is related to her obligations to fulfill the rights of other human beings, both Muslim or nonMuslim. These two frameworks describe the criteria of compliant Muslims.

The results of an exploratory qualitative analysis of the dominant dimensions in the religious behaviors of Muslim women in career according to the perspective of Islamic education found that the aspect of a firm belief in Allah Swt. is the most dominant, then morals and religious knowledge. The technical meaning of faith is a strong belief in something tangible, based on evidence. The experts in this subject define faith as 'to believe with the heart and proclaim with the tongue'; some have added 'to act with the body' [18]. 'Faith is having a sincere devotion to God with the heart, to witness with the tongue, and to act upon with the body. 
Strong faith is a unified whole of the characteristics of "Islam," "Faith," and "Ihsan." There will be no faith without surrender (Islam), and no superiority (Ihsan) without faith. Ihsan means "perfection" or "the best" or "excellence." Some hadiths, provide a several definitions: Ihsan is someone who worships God as if she saw her God, and if she is unable to imagine seeing her God, then that person imagine that verily Allah sees her actions: Ihsan is someone who has a constant behavior advantage of the faithful in all her actions and situations. Moreover, Ihsan, in its most comprehensive meaning, means more than just rites and superior acts of devotion, as the Prophet Saw. said: "Ihsan" (excellence) is to work for God as If you saw Him; because if you don't see Him, He certainly sees you," and also: Muhsin (excellence) is the fear of God as if you see Him because if you don't see Him, He will surely see you." This note is what makes excellence a constant behavior from the faithful in all their deeds and situations stated as-Sunnah Imam Muslim.

Faith has an impact on a person's overall actions. Faith has a variety of meanings. Faith is positive energy, a driving force, and has the effect of continuing to do good deeds, always obeying commands, and avoiding God's prohibitions [18]. Al-Jifri [18] further asserted that human fortitude and excellence in the workplace, clarity in how to operate, the stability of decision making, disruption of feelings of greed and fear, avoiding fraud and avoiding anything that can affect the quality or continuity of work is the effect of faith at work.

\section{Conclusion}

The results of the research showed that first, the personality characteristics of Indonesian Muslims who are pursuing a career in the digital age have full faith, diligent worship, and noble characters. Second, the dimensions of behavior and religiosity of Muslim women in careers in the digital age are related to the aspects of trust, the dimensions of worship or religious practices, the dimensions of practice and consequences, as well as the dimensions of religious knowledge. To sum up, this study concludes that religiosity is the implication of the depth, maturity, and maturity of Muslim women. Muslim women can be said to be religious women, manifested in career life, shaped solely through an integrated dimension. The digital age is a tool and facility to a place of tawhid as a guide in careers. Both are fundamental truths and dogmatic teachings.

\section{References}

[1] L. Muhtifah and R. T. Muskania, "The Design on Quality System Model of FTIK IAIN Pontianak in SNPT 2015 and QMS ISO 9001:2015," J. Pendidik. Islam, vol. 7, no. 2, pp. 383-404, 2018, doi: https://doi.org/10.14421/jpi.2018.72.383-404.

[2] Q. M. . Shamsuddin, "Dimensions of Muslim Religiosity: Measurement Considerations," in Qur'anic Concepts of human Psyche, ed. Zafar Maq Ansari. Islamabad: Institute of Islamic Culture., 1992.

[3] and J. R. Magill, Frank N., Survey of social science. Pasadena Calif: Salem Press, 1993.

[4] M. Salleh, "Religiosity in Development: A Theoretical Construct of an Islamic-Based Development," Int. J. Humanit. Soc. Sci., vol. 2, no. 14, pp. 266-274, 2012, doi: http://www.ijhssnet.com/journals/Vol_2_No_14_Special_Issue_July_2012.

[5] S. Al-Goaib, "Religiosity and Social Conformity of university students: An Analytical Study Applied at King Saud University," Arts J. King Saud Univ., vol. 16, no. 1, pp. 
51-99, 2003.

[6] and C. A. L. Morgan, Peggy, Ethical Issues in Six Religious Traditions, 2nd ed. Edinburgh: Edinburgh University Press, 2007.

[7] N. R. M. Mohsen, “Leadership From The Qur'an Relationship Between Taqwa, Trust And Business Leadership Effectiveness," 2007.

[8] E. S. Krauss, R. Hamzal, Azimi, Juhari, and J. Abdul Hamid, "The Muslim Religiosity-Personality Inventory (MRPI): Towards Understanding Differences in the Islamic Religiosity among the Malaysian Youth,” Pertanika J. Soc. Sci., p. 177, 2005.

[9] Mahudin at al, "Religiosity among Muslims: A Scale Development and Validation Study," Hubs-Asia, 2016, doi: http://doi.org/10.7454/mssh.v20i2.480.

[10] and S. A. B. Azmi, Ilhaamie Abdul Ghani, Sharifah Hayaati Syed Ismail, "Women Career Advancement in Public Service: A Study in Indonesia," in Procedia - Social and Behavioral Sciences, 2012, doi: . http://doi.org/10.1016/j.sbspro.2012.09.1004.

[11] P. Offenhauer, "Women in Islamic Societies: A Selected Review of Social Scientific Literature," 2005. .

[12] B. Stowasser, "Women in the Qur'an,” Tradit. Interp, p. 98, 1994.

[13] D. Amir, "Konsep Manusia Dalam Sistem Pendidikan Islam,” Al-Ta Lim J., 2012.

[14] Kania, D. Dewi, W. Zarman, and T. And Romly, "Value Education in The Perspective of Western and Islamic Knowledge," At-Ta'dib, vol. 12, no. 2, p. 1, 2017, doi: https://doi.org/10.21111/at-tadib.v12i2.1194.

[15] M. Mansoer, Perilaku Keberagamaan Remaja Kasus Pada Siswa SLTA Di Kota Jakarta Selatan, Kabupaten Sukabumi dan Kabupaten Lebak. Bogor: Unpublised Dissertation of InstitutPertanian Bogor, 2008.

[16] I. Diati, Hubungan antara Religiusitas intrinsik dan Religiusitas Ekstrinsik dengan Sikap Terhadap Aborsi yang Disengaja. Jakarta: Unpublishing Thesis of Psychology Faculty of Universitas Indonesia Jakarta, 2000.

[17] and J. M. R. Allport, Gordon W., "Personal Religious Orientation and Prejudice," J. Pers. Soc. Psychol., pp. 33-35, 1967, doi: http://doi.org/10.1037/h0021212.

[18] H. A. Al-Jifri, "The Concept of Faith in Islam," 2012. . 